\title{
Evaluasi Keselamatan Kerja Listrik Laboratorium Permesinan Kapal Universitas Maritim AMNI Semarang Dengan Metode Analitycal Network Process (ANP)
}

\author{
Sunu Arsy Pratomo a*, Bayu Murti ${ }^{\text {b }}$ \\ ${ }^{\mathrm{a}, \mathrm{b}}$ Universitas Maritim AMNI Semarang \\ a*Email: shoeyzero@gmail.com, \\ bEmail: ir.bayu@gmail.com
}

\begin{abstract}
ABSTRAK
Dalam pengoperasian komponen listrik di laboratorium permesinan kapal Universitas Maritim AMNI Semarang dibutuhkan berbagai macam proteksi. Kesalahan instalasi dan pengoperasian peralatan listrik dapat menurunkan proteksi. Proteksi ini bertujuan untuk meningkatkan keselamatan kerja listrik pada laboratorium permesinan kapal. Dan dalam penerapan keselamatan kerja listrik perlu dilakukan evaluasi berdasarkan standar Persayaratan Umum Instalasi Listrik 2000 (PUILL 2000). Tujuan penelitian ini adalah untuk mengevaluasi penggunaan laboratorium Universitas Maritim AMNI Semarang dalam aspek keselamatan kerja. Berdasarkan hasil evaluasi ditentukan kriteria keselamatan kerja listrik yaitu : proteksi untuk keselamatan, proteksi dari tegangan dan arus lebih, proteksi dari efek termal dan proteksi dari arus gangguan. Setelah dilaksanakan evaluasi didapatkan alternatif untuk meningkatkan keselamatan kerja listrik yaitu : standard operating procedeure (SOP), Pemeriksaan instalasi kabel, Pengecekan Panel MCB dan saklar. Dari kriteria dan alternatif yang didapatkan kemudian diolah menggunakan software super decision ver.2.10.0 dengan metode Analytical Network Process (ANP) sehingga didapatkan hasil prioritas perbaikan keselamat kerja listrik pada laboratorium permesinan kapal Universitas Maritim AMNI Semarang adalah : perbaikan SOP 63,7\%, Instalasi Kabel 25,8\%, Panel MCB dan saklar10,5\%.
\end{abstract}

Kata Kunci : laboratorium, keselamatan kerja kistrik, PUILL 2000, ANP

\section{ABSTRACT}

In the operation of electrical components in the ship engineering laboratory of the Maritime University of AMNI Semarang, various kinds of protection are needed. Errors in installing and operating electrical equipment can reduce protection. This protection aims to improve the safety of electrical work in ship engineering laboratories. And in the application of electrical work safety, it is necessary to evaluate based on the 2000 Electrical Installation General Requirements standard (PUILL 2000). The purpose of this study was to evaluate the use of the laboratory of the Maritime University of AMNI Semarang in the aspect of work safety. Based on the results of the evaluation, the criteria for electrical work safety are determined, namely: protection for safety, protection from overvoltages and currents, protection from thermal effects, and protection from fault currents. After the evaluation was carried out, alternatives were found to improve electrical safety: standard operating procedure (SOP), an inspection of cable installations, checking MCB panels and switches. The criteria and alternatives obtained then processed using the software super decision ver.2.10.0 with the Analytical Network Process (ANP) method so that the priority results of electrical safety improvements in the ship engineering laboratory of AMNI Maritime University Semarang are: repair of SOP 63.7\%, Cable Installation 25.8\%, MCB Panel, and $10.5 \%$ switch.

Keywords: laboratory, electrical work safety, PUIL 2000, ANP 


\section{PENDAHULUAN}

Laboratorium pendidikan pada perguruan tinggi merupakan unit penunjang akademik yang digunakan untuk melaksanakan kegiatan pendidikan, penelitian dan pengabdian kepada masyarakat dengan menggunakan peralatan dan bahan berdasarkan metode keilmuan tertentu. Seperti teori dan konsep-konsep, percobaan di laboratorium adalah hal penting untuk pendidikan ilmu alam, teknologi, teknik, dan matematika (Kolil, Muthupalani, \& Achuthan, 2020) serta biologi (Reece \& Butler, 2017). Pada pendidikan ilmu alam dan teknik, praktik percobaan memainkan peran penting (Heradio, de la Torre, Galan, Cabrerizo, Herrera-Viedma, \& Dormido, 2016); (Lasica, Katzis, MeletiouMavrotheris, \& Dimopoulos, 2016). Dengan mata kuliah berbasis pengalaman penelitian bisa meningkatkan dan memperluas partisipasi para mahasiswa dalam penelitian yang otentik (McLaughlin, Favre, Weinstein, \& Goedhart, 2017). Dengan mengikuti kuliah di laboratorium akan mengajarkan para mahasiswa konsep-konsep ilmiah dan juga keterampilan (Faulconer, Faulconer, \& Hanamean, 2019). Bahkan, di era sekarang sudah terdapat laboratorium virtual yang dinilai efektif dalam pembelajaran (Miller, Carver, \& Roy, 2018).

Laboratorium permesinan kapal adalah sarana yang disediakan untuk para taruna belajar tentang bagianbagian mesin penggerak utama dan mesin bantu untuk kapal serta dapat menanganinya apabila terjadi suatu masalah sehingga kapal dapat berjalan. Laboratorium tersebut merupakan sarana yang penting dan bersifat strategis dalam pelaksanaan sistem pendidikan khususnya di perguruan tinggi. Sarana pendidikan mencakup semua peralatan dan perlengkapan yang secara langsung menunjang proses pendidikan sedangkan prasarana pendidikan mencakup semua peralatan dan perlengkapan yang secara

https://doi.org/10.46484/db.v2i1.253 tidak langsung menunjang proses pendidikan (Kertiasih \& Putu, 2016).

Di dalam laboratorium ini terdapat berbagai macam peralatan dan komponen elektronika yang digunakan untuk melaksanakan pembelajaran. Karena banyaknya komponen dan peralatan listrik maka mutlak diperlukan penerapan keselamatan kerja listrik. Keselamatan kerja listrik adalah keselamatan kerja yang bertalian dengan alat, bahan, proses, tempat (lingkungan) dan cara-cara melakukan pekerjaan. Tujuan dari keselamatan kerja listrik adalah untuk melindungi tenaga kerja atau orang dalam melaksanakan tugastugas atau adanya tegangan listrik disekitarnya, baik dalam bentuk instalasi maupun jaringan. Pasalnya, kabel yang nampaknya tidak berbahaya tidak pernah dapat dilihat secara langsung berapa jumlah tegangannya yang bisa menjadi penyebab utama kecelakaan listrik (Ghosh, Basak, Ghosh, Balow, \& Dey, 2015). Sehingga, pekerjaan yang berkaitan dengan listrik dapat menyebabkan kecelakan yang serius (Wong, Chan, Wong, Hon, \& Choi, 2018) yang bisa mengakibatkan komplikasi dengan resiko tinggi (Gille, et al., 2018). Pada dasarnya keselamatan kerja listrik adalah tugas dan kewajiban dari, oleh dan untuk setiap orang yang menyediakan, melayani dan menggunakan daya listrik. Undang undang no. 1 tahun 1970 adalah undang undang keselamatan kerja, yang di dalamnya telah diatur pasal-pasal tentang keselamatan kerja untuk pekerjapekerja listrik dan pengguna layanan listrik (Ismara, Ima, \& Prianto, 2016).

Tujuan penelitian ini adalah untuk mengevaluasi penggunaan laboratorium Universitas Maritim AMNI Semarang dalam aspek keselamatan kerja. Oleh karena itu dalam menggunakan fasilitas laboratorium harus dilakukan evaluasi keselamatan kerja listrik. Tujuan dari evaluasi ini adalah untuk melindungi tenaga kerja dan orang dalam melaksanakan tugastugas atau adanya tegangan listrik 
disekitarnya, baik dalam bentuk instalasi maupun jaringan ini termasuk dalam pengoperasian peralatan listrik dan penggunaan peralatan penunjang keselamatan. Evaluasi keselamatan kerja listrik pada laboratorium permesinan kapal berdasarkan Persayaratan Umum Instalasi Listrik 2000 (PUILL 2000) dan peraturan lainnya seperti ; undang undang Nomor 1 Tahun 1970 tentang keselamatan kerja beserta peraturan pelaksanaannya, undang - undang Nomor 23 Tahun 1997 tentang Pengelolaan Lingkungan Hidup, undang - undang Nomor 30 Tahun 2009 tentang Ketenagalistrikan.

\section{METODE PENELITIAN}

Metode yang digunakan dalam evaluasi keselamatan kerja listrik di laboratorium Universitas Maritim AMNI Semarang adalah PUILL 2000 sedangkan untuk analisa perhitungan tingkat keselamatan kerja listrik menggunakan metode Analytic Network Process (ANP).

1. Persayaratan Umum Instalasi Listrik 2000 (PUILL 2000)

Peraturan instalasi listrik yang pertama kali digunakan sebagai pedoman beberapa instansi yang berkaitan dengan instalasi listrik adalah AVE (Algemene Voorschriften voor Electrische Sterkstroom Instalaties) yang diterbitkan sebagai Norma N 2004 oleh Dewan Normalisasi Pemerintah Hindia Belanda. Kemudian AVE N 2004 ini diterjemahkan ke dalam bahasa Indonesia dan diterbitkan pada tahun 1964 sebagai Norma Indonesia NI6 yang kemudian dikenal sebagai Peraturan Umum Instalasi Listrik disingkat PUIL 1964, yang merupakan penerbitan pertama dan PUIL 1977 dan 1987 adalah penerbitan PUIL yang kedua dan ketiga yang merupakan hasil penyempurnaan atau revisi dari PUIL sebelumnya, maka PUIL 2000 ini merupakan terbitan ke 4. Jika dalam penerbitan PUIL 1964, 1977 dan 1987 nama buku ini adalah Peraturan Umum Instalasi Listrik, maka pada penerbitan tahun 2000, namanya menjadi Persyaratan Umum Instalasi Listrik dengan tetap mempertahankan singkatannya yang sama

https://doi.org/10.46484/db.v2i1.253 yaitu PUIL (Persyaratan Umum Instalasi Listrik, 2000). Dalam evaluasi keselamatan kerja listrik pada laboratorium permesinan kapal Universitas Maritim AMNI Semarang terdiri dari beberapa bagian yaitu:

a. Persyaratan listrik pada laboratorium, terdiri dari :

1) Kontinuitas suplai daya, dengan cara disediakan suplai listrik cadangan ketika suplai daya utama terganggu. Suplai daya cadangan berupa generator set.

2) Keamanan instalasi listrik, pengaman terhadap gangguan listrik sangat diperlukan karena menyangkut keselamatan taruna dalam melaksanan praktek.

3) Besaran - besaran listrik sesuai dengan standar, yaitu tegangan, arus, frekuensi, sistem pengaman, dan sistem grounding harus diperhatikan karena menentukan baik tidaknya sistem instalasi listrik. Sistem instalasi listrik dibagi menjadi instalasi penerangan dan instalasi daya listrik. Instalasi penerangan merupakan instalasi listrik yang digunakan untuk memberikan daya listrik pada lampu atau peralatan listrik lainnya. Instalasi penerangan dibagi menjadi instalasi dalam gedung dan instalasi pada luar gedung. Sedangkan instalasi daya listrik adalah suatu jaringan atau rangkaian untuk menyuplai dan menyalurkan daya listrik melalui sumber menuju beban. Instalasi daya listrik terdiri dari beberapa bagian yaitu : penyedia tenaga listrik, sistem pembagian daya listrik (grouping), saluran daya listrik, pengaman dan pertanahan (grounding)

b. Persyaratan dasar instalasi listrik, terdiri dari :

1) Proteksi untuk keselamatan, dimaksudkan untuk menjamin keselamatan manusia dan keamanan peralatan laboratorium dari bahaya dan kerusakan yang bisa ditimbulkan oleh penggunaan 
instalasi listrik secara wajar. Pada instalasi listrik terdapat dua jenis resiko utama yaitu ;

a) Arus kejut listrik,

b) Suhu berlebih yang dapat menyebabkan kebakaran, luka bakar atau efek cedera lain.

2) Proteksi dari kejut listrik, terdapat dua jenis proteksi yang harus diperhatikan yaitu ;

a) Proteksi dari sentuh langsung yang bisa timbul karena sentuhan langsung dengan bagian aktif dari instalasi. Mencegah arus langsung mengalir melalui badan manusia dan membatasi arus yang dapat mengalir melalui badan sampai suatu nilai yang lebih kecil dari arus kejut.

b) Proteksi dari sentuh tak langsung yang timbul karena sentuhan dengan bagian konduktif terbuka dalam keadaan gangguan. Mencegah mengalirnya arus gangguan melalui badan manusia, membatasi besar arus gangguan sampai dengan nilai yang lebih kecil dari arus kejut dan pemutusan suplai otomatis yang ditentukan pada saat terjadinya gangguan.

3) Proteksi dari efek termal, instalasi listrik harus disusun dengan baik sehingga menghilangkan risiko tersulutnya bahan yang mudah terbakar karena tingginya suhu atau busur api listrik. Demikian pula mencegah risiko terjadinya luka bakar pada manusia selama perlengkapan listrik beroperasi secara normal.

4) Proteksi dari arus lebih, dapat dilakukan dengan komponen pemutusan secara otomatis sebelum arus mencapai batas berbahaya dan pembatasan arus lebih maksimum.

5) Proteksi dari arus gangguan, selain penghantar aktif dan bagian lain yang dimaksudkan untuk menyalurkan arus gangguan harus mampu menyalurkan arus tersebut tanpa menimbulkan suhu yang berlebihan.

6) Proteksi dari tegangan lebih, manusia harus dicegah dari cedera dan peralatan laboratorium harus dicegah dari setiap efek yang berbahaya akibat adanya gangguan antara bagian aktif sirkuit yang disuplai dengan tegangan yang berbeda dan sebab lain (misalnya, fenomena atmosfer atau tegangan lebih penyakelaran).

Selain persyaratan diatas pada komponen instalasi listrik harus dipenuhi beberapa syarat yang telah diatur pada PUILL 2000 yaitu setiap perlengkapan listrik harus tercantum dengan jelas :

1) Nama pembuat dan atau merek dagang.

2) Daya, tegangan, dan/atau arus pengenal.

3) Data teknis lain seperti disyaratkan SNI. Instalasi listrik yang sudah memenuhi semua ketentuan tersebut dalam dapat dioperasikan setelah mendapat izin atau pengesahan dari instansi yang berwenang dengan syarat tidak boleh dibebani melebihi kemampuannya.

c. Persyaratan kabel penghantar kuat hantar listrik (KHA) yang harus dipenuhi. KHA tersebut akan bernilai aktual $100 \%$ bila kabel tersebut dipasang pada temperatur kelilingnya maksimal $30^{\circ}$ C. Tetapi bila suhu keliling melebihi nilai tersebut maka akan terjadi penurunan nilai aktual KHA. Berdasarkan PUIL 2000 pasal 5.5.3.1 menyatakan bahwa "penghantar sirkuit akhir yang menyuplai motor tunggal tidak boleh mempunyai KHA 
kurang dari $125 \%$ arus pengenal beban penuh". Untuk rumus perhitungan KHA adalah :

Untuk Arus Searah :

In $=$ P/V (A)

Untuk Arus Bolak-balik Satu Fasa:

In $=P /(V \cdot \operatorname{Cos} \varphi)(A)$

Untuk Arus Bolak-balik tiga Fasa:

$\mathrm{In}=\mathrm{P} /(. \mathrm{V} \cdot \operatorname{Cos} \varphi)(\mathrm{A})$

$\mathrm{KHA}=125 \% \mathrm{X}$ In

Keterangan :

$\mathrm{I}=$ Arus Nominal Beban Penuh (A)

$\mathrm{P}=$ Daya Aktif $(\mathrm{W})$

$\mathrm{V}=$ Tegangan $(\mathrm{V})$

$\operatorname{Cos} \varphi=$ Faktor Daya

d. Persyaratan pemutus rangkaian, Miniatur Circuit Breaker (MCB) atau pemutus tenaga memiliki fungsi sebagai pemutus suatu rangkaian apabila ada arus yang mengalir dalam rangkaian atau beban listrik yang melebihi kemampuan. Contohnya saat terjadi konsleting dan lainnya. Pemutus tenaga ini ada dua macam yaitu satu phase dan 3 phase, untuk pemutus tenaga 3 phase terdiri dari tiga buah pemutus tenaga 1 phase yang disusun menjadi satu kesatuan. Pemutus tenaga mempunyai 2 posisi, saat menghubungkan maka antara terminal masukan dan terminal keluaran MCB akan terjadi kontak. Pada posisi saat ini MCB pada kedudukan $1(\mathrm{ON})$, dan saat ada gangguan MCB dengan sendirinya akan melepas rangkaian secara otomatis kedudukan saklarnya 0 (OFF), saat ini posisi terminal masukan dan keluaran MCB tidak tersambung. Dalam pemilihan MCB ditentukan oleh dua hal, yaitu :

1) SPLN 108 / SLI 175, bila digunakan oleh pemakai umum (instalasi perumahan - kapasitas pemutusan rendah).
2) IEC 60947-2, bila digunakan oleh ahlinya (aplikasi industri - kapasitas pemutusan tinggi).

Kapasitas suatu pemutus tenaga harus lebih besar dari arus hubung singkat pada titik instalasi di mana pemutus tenaga tersebut terpasang. Pada diagram garis suatu sistem, disarankan untuk juga menyebutkan besar kapasitas pemutusan di samping arus pengenal pemutus tenaga yang digunakan.

2. Analytical Network Process (ANP)

Analytic Network Process (ANP) adalah teori matematis yang memiliki kemampuan dalam menganalisa pengaruh dengan pendekatan asumsi-asumsi untuk menyelesaiakan bentuk permasalahan. ANP sebagai suatu pendekatan alternatif baru untuk studi kualitatif yang apat mengkombinasikan nilai-nilai intangible dan jugement subyektif dengan data-data statistik dan faktor-faktor tangible lainnya (Saaty \& Vargas, 2006). Metode ini digunakan dalam bentuk penyelesaian dengan pertimbangan atas penyesuaian kompleksitas masalah disertai adanya skala prioritas yang menghasilkan pengaruh prioritas terbesar.

ANP adalah generalisasi dari Analytic Hierarchy Process (AHP), dengan mempertimbangakan ketergantungan antara unsur-unsut dari hirarki.banyak masalah keputusan tidak dapat tersetruktur secara hirarkis karena mereka melibatkan interaksi dan ketergantungan unsur-unsur tingkat yang lebih tinggi dalam hirarki dielemen level yang lebih rendah ( (Saaty \& Vargas, 2006) Banyak proses pengambilan keputusan suatu persoalan tidak dapat disusun dalam bentuk hirarki karenan melibatkan interaksi dan ketergantungan elemen-elemen yang lebih tinggi tingkatannya kepada level elemen yang lebih rendah. Metode ANP memiliki kemampuan dalam memperbaiki kelemahan AHP dengan cara mengakomodasi keterkaitan antar kritera atau alternatif. Komponen ANP terdiri dari hirarki kontrol, cluster, elemen, hubungan set elemen (inner dependence) dan 
keterkaitan antar elemen yang berbeda (outer dependence).

Langkah-langkah yang perlu dilakukan dalam permdelan ANP adalah :

a. Mendefinisikan masalah dan menentukan kriteria dari solusi yang diinginkan.

b. Menentukan pembobotan pada tiap komponen pandang manajerial. Pada tabel 2 adalah pedoman yang digunakan untuk pemberian nilai dalam perbandingan berpasangan. Pembobotan menggunakan skala kuantitatif 1 sampai dengan 9 untuk menilai perbandingan tingkat kepentingan suatu elemen terhadap elemen lainnya (Saaty \& Vargas, 2006).

c. Selanjutnya membuat Matrix Pairwise Comparison. Matrix tersebut adalah perbandingan pengambil keputusan dengan menilai tingkat kepentingan suatu kriteria. Skala 1 sampai 9 digunakan untuk perbandingan berpasangan dalam mengukur kepentingan relatif dari satu kriteria dengan kriteria yang lain.

\section{Langkah Penelitian}

Penelitian ini dilaksanakan pada laboratorium permesinan kapal Universitas Maritim AMNI dilaksanakan dalam beberapa tahapan yaitu :

a. Evaluasi intalasi listrik berupa pemeriksaan dan pendataan kabel penghantar berdasarkan PUILL 2000.

b. Evaluasi dan pendataan MCB yang terpasang pada beberapa peralatan yang menggunakan listrik berdasarkan PUILL 2000.

c. Evaluasi keselamatan kerja listrik dengan metode wawancara pada unit pengelola laboratorium perihal pengelolaan peralatan yang menggunakan listrik dan standard operating procedure (SOP).

d. Menentukan kriteria dan alternatif standar keselamatan kerja listrik pada laboratorium berdasarkan hasil evaluasi.

e. Perhitungan dengan ANP untuk mendapatkan rekomendasi peningkatan standar keselamatan kerja listrik pada laboratorium.

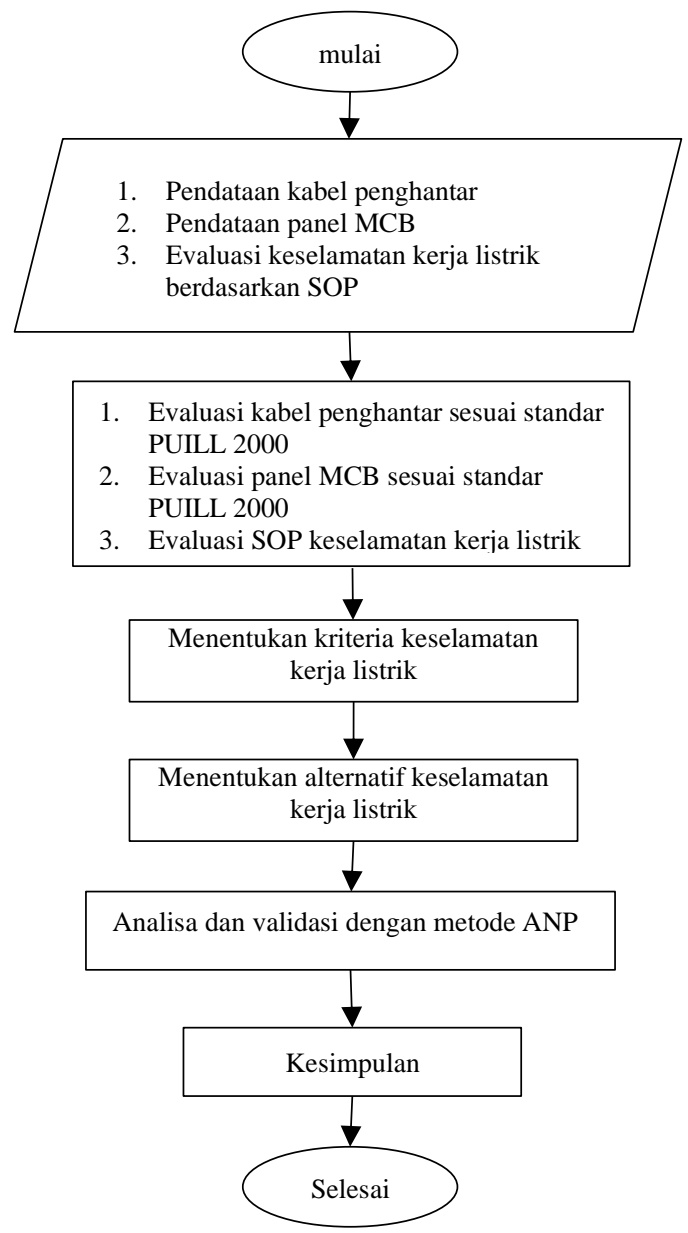

Gambar 1. Diagram Alir Penelitian

4. Menentukan Kriteria dan Alternatif ANP

Penggunaan metode ANP adalah dengan mengurai permasalahan yang ada menjadi beberapa cluster kriteria dan cluster alternatif. Kriteria ditentukan berdasarkan persyaratan dasar instalasi listrik dari PUILL 2000. Sedangkan alternatif ditentukan dari keselamatan kerja listrik berdasarkan dari sumber internal dan external dari unit laboratorium permesinan 
kapal. Masing-masing kriteria diberi bobot dengan melakukan perbandingan antara kriteria terhadap alternative. Kombinasi dari tahapan tersebut digabungkan dengan teori dari ANP akan menghasilkan nilai akhir untuk setiap alternatif. Alternatif dengan nilai tertinggi pada akhir pengujian adalah alternatif terbaik. Model dari penelitian ini dapat dilihat pada gambar 3 .

Kriteria yang digunakan dalam penelitian ini adalah :

a. Proteksi untuk keselamatan, untuk melindungi manusia dan keamanan peralatan laboratorium dari terjadinya arus kejut listrik.

b. Proteksi dari efek termal, yaitu perlindungan terhadap risiko tersulutnya bahan yang mudah terbakar karena tingginya suhu atau busur api.

c. Proteksi dari arus dan tegangan lebih, proteksi arus lebih dengan cara pemutusan secara otomatis sebelum arus dan tegangan mencapai batas berbahaya.

d. Proteksi dari arus gangguan, yaitu dengan menyalurkan arus gangguan tanpa menimbulkan suhu yang berlebihan (grounding).

Sedangkan alternatif yang digunakan pada penelitian ini adalah :

1. Instalasi Kabel

a. Evaluasi kabel penghantar yang digunakan pada peraltan listrik apakah sudah sesuai standar yang ada.

b. Pemeriksaan kabel listrik terjadi kerusakan atau tidak, misal : kabel terkelupas, kabel terbakar.

2. Panel MCB dan Saklar

a. Penggunaan MCB dan pemutus daya pada setiap peralatan listrik.

b. Penggunaan MCB yang sesuai dengan daya yang dibutuhkan.

c. Pemeriksaan fungsi MCB apakah bekerja sesuai dengan fungsinya.

3. Standard Operating Procedure (SOP)

a) Prosedur operasional peralatan listrik b) Peralatan keselamatan kerja listrik, misal : sarung tangan, helem, sepatu.

c) Tanda peringatan bahaya sengatan listrik di setiap panel MSB/MCB.

d) Peralatan penanggulangan terjadinya kecelakaan, misal : alat pemadam kebakaran (APAR) dan kotak peralatan pertama pada kecelakaan (P3K).

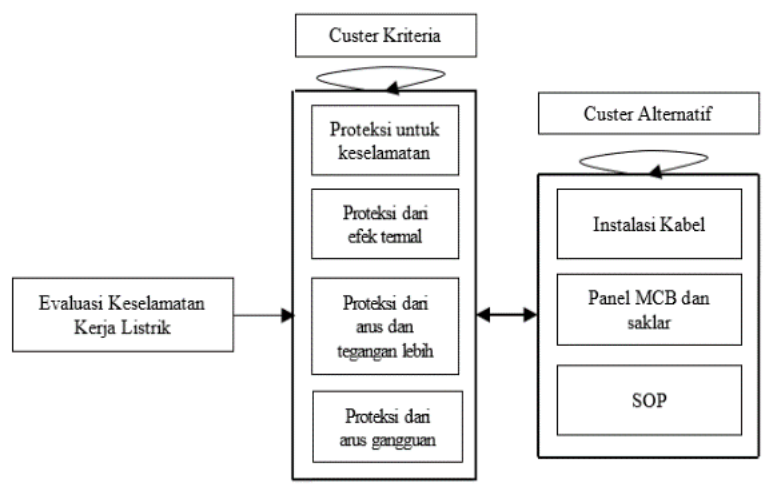

Gambar 3. Model evaluasi keselamatan kerja listrik (Super Decision ver.2.10.0)

\section{HASIL DAN ANALISA}

Berdasarkan dari data inventaris dan hasil evaluasi komponen peralatan listrik yang tersedia di laboratorium permesinan kapal adalah :

Tabel 4. Komponen Peralatan Listrik Laboratorium Permesinan Kapal Unimar AMNI Semarang

\begin{tabular}{|l|l|l|l|l|}
\hline No & \multicolumn{1}{|c|}{$\begin{array}{c}\text { Peralatan } \\
\text { Listrik }\end{array}$} & $\begin{array}{c}\text { Arus } \\
(\mathbf{A})\end{array}$ & $\begin{array}{c}\text { Tegan } \\
\text { gan } \\
(\mathbf{V})\end{array}$ & $\begin{array}{c}\text { Daya } \\
(\mathbf{W})\end{array}$ \\
\hline 1 & $\begin{array}{l}\text { Kompressor } \\
\text { udara pejalan }\end{array}$ & 1,8 & 380 & 684 \\
\hline 2 & $\begin{array}{l}\text { Boiler dan } \\
\text { pemanas } 1\end{array}$ & 1,2 & 380 & 456 \\
\hline 3 & $\begin{array}{l}\text { Boiler dan } \\
\text { pemanas } 2\end{array}$ & 0,2 & $120 \mathrm{~K}$ & 2400 \\
\hline 4 & $\begin{array}{l}\text { Pompa } \\
\text { sentrifugal }\end{array}$ & 2,4 & 380 & 912 \\
\hline 5 & Pompa ulir & 2,4 & 380 & 912 \\
\hline 6 & Pompa roda gigi & 2,4 & 380 & 912 \\
\hline 7 & Pompa torak & 2,4 & 380 & 912 \\
\hline 8 & Oil purifier 1 & 7,4 & 380 & 2812 \\
\hline 9 & Oil purifier 2 & 7,4 & 380 & 2812 \\
\hline 10 & $\begin{array}{l}\text { Oil water } \\
\text { separator }\end{array}$ & 5,7 & 380 & 2166 \\
\hline 11 & Steering gear & 1,4 & 380 & 532 \\
\hline
\end{tabular}

Berdasarkan data komponen peralatan listrik pada tabel 4. dapat diambil 
kesimpulan bahwa daya listrik yang dipergunakan cukup besar. Rata-rata jaringan listrik yang dipergunakan adalah jaringan 3 phase. Maka berdasarkan hal tersebut keselamatan kerja listrik mutlak dibutuhkan. Langkah yang dilakukan berdasarkan evaluasi keselamatan kerja listrik adalah sebagai berikut :

1. Evaluasi Instalasi kabel

Setelah dilakukan evaluasi di laboratorium permesinan kapal didapatkan intalasi kabel menggunakan jenis NYM berbahan PVC berstandar SNI 04-6629.4 diameter $4 \times 2,5 \mathrm{~mm}^{2}$ kemampuan hantar tegangan 300/500 V. Instalasi kabel juga ditambahkan pelindung kabel berbahan plastik tahan api. Berdasarkan evaluasi dapat disimpulkan bahwa instalasi kabel pada laboratorium permesinan kapal sudah memenuhi standar.
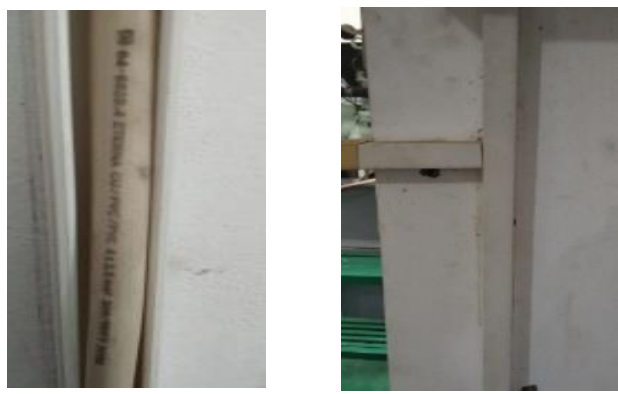

Gambar 4. Kabel instalasi dan pelindung Lab. Permesinan Kapal Unimar Amni Semarang

2. Evaluasi MCB dan pemutus tenaga

Pada setiap komponen peralatan listrik di laboratorium permesinan kapal telah dilengkapi dengan MCB dan saklar pemutus tenaga. MCB dan saklar pemutus tenaga yang digunakan sudah berstandar SNI. Berdasarkan evaluasi dapat disimpulkan bahwa keamanan komponen peralatan listrik laboratorium permesinan kapal sudah memenuhi standar.
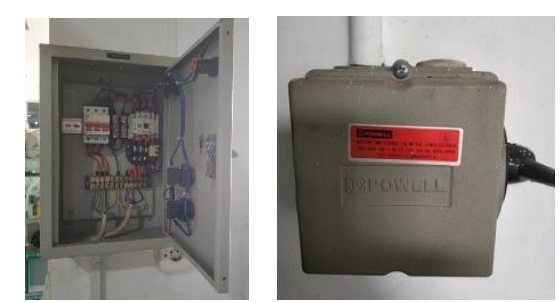

Gambar 5. MCB dan saklar pemutus tenaga Lab. Permesinan Kapal Unimar Amni Semarang

3. Pemeriksaan SOP dan peralatan keselamatan kerja listrik

Setiap komponen peralatan listrik di laboratorium permesinan kapal sudah diberi petunjuk pengoperasian. Komponen keselamatan kerja listrik berupa sarung tangan, sepatu khusus dan helm sudah tersedia. Alat pemadam api ringan (APAR) tersedia di lokasi yang mudah dijangkau. Namun masih ada komponen keselamatan kerja listrik yang belum terpenuhi yaitu tanda bahaya sengatan listrik belum terpasang pada beberapa panel yang MCB. Kesimpulan yand didapatkan adalah SOP keselamatan kerja listrik perlu ditingkatkan.

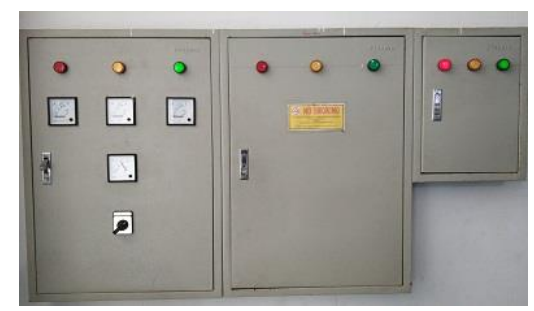

Gambar 5. Sub distribution panel (SDP) Lab.

Permesinan Kapal Unimar Amni Semarang

Berdasarkan evaluasi yang telah dilakukan maka prioritas dari setiap kriteria keselamatan kerja listrik di laboratorium permesinan kapal dapat disimpulkan sebagai berikut :

1. Proteksi untuk keselamatan

2. Proteksi dari tegangan dan arus lebih

3. Proteksi dari efek termal

4. Proteksi dari arus gangguan

Untuk urutan alternatif keselamatan kerja listrik pada laboratorium permesinan 
kapal ditentukan prioritasnya sebagai berikut :

1. SOP : proteksi untuk keselamatan, proteksi dari tegangan dan arus lebih, proteksi dari efek termal dan proteksi dari arus gangguan.

2. Instalasi kabel : proteksi dari efek termal, proteksi dari tegangan dan arus lebih, proteksi untuk keselamatan dan proteksi dari arus gangguan.

3. Panel MCB dan Saklar : proteksi dari tegangan dan arus lebih, proteksi dari arus gangguan, proteksi untuk keselamatan dan proteksi dari efek termal.

Perhitungan prioritas keselamatan kerja listrik pada laboratorium permesinan kapal dengan metode ANP menggunakan alat bantu berupa software Super Decision ver .2.10.0. Proses perhitungan pada penelitian ini dilakukan dalam tiga tahap yaitu : pembobotan dalam cluster kriteria, pembobotan pada cluster alternatif dan yang terakhir pembobotan pada semua cluster.

Pada saat perancangan perhitungan dengan metode ANP maka disusun hirarki yang dapat dilihat pada gambar 6. Struktur dari hirarki terdapat tiga buah cluster yaitu : cluster pertama adalah tujuan dari penelitian, cluster kedua adalah kriteria dan cluster ketiga adalah alternatif.

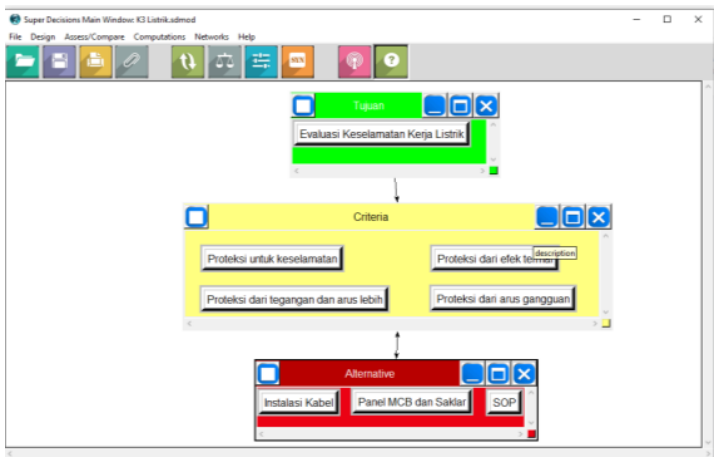

Gambar 6. Struktur cluster dan node ANP (Super Decision ver.2.10.0)

Setelah ditentukan struktur cluster dari ANP maka dilakukan pembobotan berdasarkan prioritas yang telah ditentukan. Di dalam ANP setiap node di dalam kriteria maupun alternatif mempunyai kedudukan yang sama. Pembobotan ini didapatkan dari

https://doi.org/10.46484/db.v2i1.253 evaluasi keselamatan kerja listrik yang telah dilakukan. Struktur pembobotan pada ANP dapat dilihat pada gambar 7 .

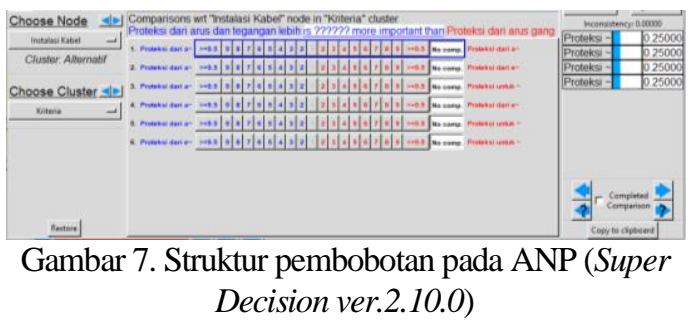

Setelah dilakukan pembobotan pada tiap cluster pada kriteria dan alternatif, perhitungan supermatrix dan perhitungan inkonsistensi didapatkan hasil akhir sebagai berikut :

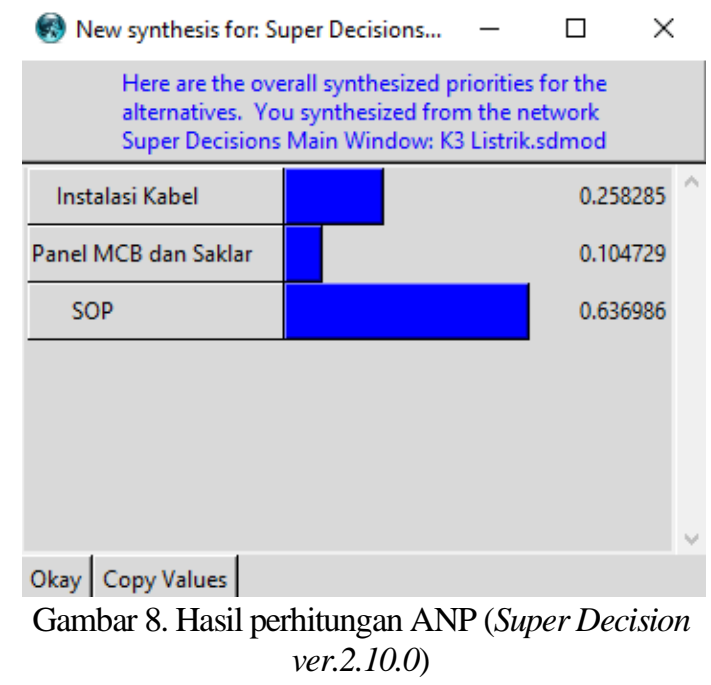

Dari hasil perhitungan tersebut didapatkan perangkingan rekomendasi keselamatan kerja listrik di laboratorium permesinan kapal pada tabel 5 .

Tabel 5. Hasil akhir perhitungan ANP (Super Decision ver.2.10.0)

\begin{tabular}{|l|c|l|}
\hline Alternatif & Rangking & Nilai \\
\hline SOP & 1 & 0.636986 \\
\hline Instalasi Kabel & 2 & 0.258285 \\
\hline $\begin{array}{l}\text { Panel MCB dan } \\
\text { Saklar }\end{array}$ & 3 & 0.104729 \\
\hline
\end{tabular}

\section{SIMPULAN}

Berdasarkan evaluasi yang telah dilakukan maka didapatkan prioritas dari setiap kriteria keselamatan kerja listrik di laboratorium permesinan kapal adalah : proteksi untuk keselamatan, proteksi dari tegangan dan arus lebih, proteksi dari efek termal dan proteksi dari arus gangguan. 
Intalasi kabel pada laboratorium permesinan kapal menggunakan jenis NYM berbahan PVC berstandar SNI 046629.4 diameter $4 \times 2,5 \mathrm{~mm}^{2}$ kemampuan hantar tegangan 300/500 $\mathrm{V}$ dan juga terdapat pelindung kabel berbahan plastik tahan api. Maka berdasarkan hal tersebut instalasi kabel pada laboratorium permesinan kapal sudah memenuhi standar.

Setiap peralatan listrik di laboratorium permesinan kapal dilengkapi dengan panel MCB dan saklar pemutus tenaga berstandar SNI maka dapat disimpulkan keamanan komponen peralatan listrik laboratorium permesinan kapal sudah memenuhi standar.

Komponen SOP keselamatan kerja listrik pada laboratorium pemesinan kapal ada yang belum terpenuhi sehingga perlu ditingkatkan.

Dari hasil perhitungan didapatkan perangkingan rekomendasi keselamatan kerja listrik di laboratorium permesinan kapal adalah SOP 63,7 \%, Instalasi Kabel $25,8 \%$, Panel MCB dan Saklar 10,5 \%.

\section{DAFTAR PUSTAKA}

Faulconer, E., Faulconer, L., \& Hanamean, J. (2019). Arriving at a Better Answer: A Decision Matrix for Science Lab Course Format. Journal of College Science Teaching, 48(4), 31-35.

Ghosh, M. C., Basak, R., Ghosh, A., Balow, W., \& Dey, A. (2015). An Article on Electrical Safety. International Journal for Scientific Research \& Development, Vol. 3(10), 503506.

Gille, J., Schmidt, T., Dragu, A., Emich, D., Hilbert-Carius, P., Kremer, T., et al. (2018). Electrical injury - a dual center analysis of patient characteristics, therapeutic specifics and outcome predictors. Scand J Trauma Resusc Emerg Med 26, 43.

Heradio, R., de la Torre, L., Galan, D., Cabrerizo, F., Herrera-Viedma, E., \& Dormido, S. (2016). Virtual and remote labs in education: A bibliometric analysis. Computers \& Education, 98, 14-38.

Ismara, Ima, K., \& Prianto, E. (2016). Keselamatan dan kesehatan kerja di bidang kelistrikan (electric safety). Solo: Adicandra Media Grafika.

Kertiasih, \& Putu, N. L. (2016). Peranan Laboratorium Pendidikan untuk Menunjang Proses Perkuliahan Jurusan Keperawatan Gigi Poltekkes Denpasar. Jurnal Kesehatan Gigi (Dental Health Journal), 4(2), 59-66.

Kolil, V. K., Muthupalani, S., \& Achuthan, K. (2020). Virtual experimental platforms in chemistry laboratory education and its impact on experimental self-efficacy. Int J Educ Technol High Educ, 17 (30).

Lasica, I., Katzis, K., MeletiouMavrotheris, M., \& Dimopoulos, C. (2016). Research challenges in future laboratory-based stem education. Bulletin of the IEEE Technical Committee on Learning Technology, 18(1).

McLaughlin, J., Favre, D., Weinstein, S., \& Goedhart, C. (2017). The Impact of a Four-Step Laboratory Pedagogical Framework on Biology Students' Perceptions of Laboratory Skills, Knowledge, and Interest in Research. Journal of College Science Teaching, 47(1), 83-91.

Miller, T., Carver, J., \& Roy, A. (2018).

To Go Virtual or Not to Go Virtual, That is the Question: A Comparative Study of Face-ToFace Versus Virtual Laboratories in a Physical Science Course. Journal of College Science Teaching, 48(2), 59-67.

Persyaratan Umum Instalasi Listrik. (2000). Jakarta: Badan Standarisasi Nasional PUIL 2000

Reece, A., \& Butler, M. (2017). Virtually the Same: A Comparison of 
STEM Students' Content

Knowledge,

Performance, and Motivation to

Learn in Virtual and Face-to-

Face Introductory Biology

Laboratories. Journal of College

Science Teaching, 46(3), 83-89.

Saaty, T., \& Vargas, L. (2006). Decision making with the analytic network process, Economic, Political, Social and Technological Applications with Benefits, Opportunities, Costs and Risks. Pittsburgh, USA: University of Pittsburgh.

Wong, F. K., Chan, A. P., Wong, A. K., Hon, C. K., \& Choi, T. N. (2018). Accidents of Electrical and Mechanical Works for Public Sector Projects in Hong Kong. International Journal of Environmental Research and Public Health, 15 (3). 